\title{
The Distributive Effects of Joining the Global Economy in Iran: the Application of ARDL Model
}

\author{
Ali A. Naji Meidani \\ Assistant Professor of Economics, Department of Economics \\ Ferdowsi University of Mashhad, Mashhad, Iran \\ E-mail: naji@um.ac.ir \\ Maryam Zabihi (Corresponding author) \\ M.A. in Economics, Department of Economics \\ Ferdowsi University of Mashhad, Mashhad, Iran \\ E-mail:m.zabihi20@yahoo.com
}

Received: June 26, 2012 Accepted: July 10, 2012

doi:10.5296/ber.v2i2.2001ＵRL: http://dx.doi.org/10.5296/ber.v2i2.2001

\begin{abstract}
In this paper the relationship between globalization and distribution of income in Iran with using of time series data over 1977-2007 is investigated. For this purpose, we used Auto Regressive Distributed Lag (ARDL) model and long-run and short-run relations between involved variables in model are considered. The trade intensity index is used as measure of globalization. Results indicated that, there is long-run relationship and co-integration between involved variables and the Gini coefficient. Furthermore, accompanied by other variables globalization, has a positive and significant effect on dependent variable. Value of error correction coefficient is equal to -0.90 and statistically significant and suggests a high speed of convergence to equilibrium.
\end{abstract}

Keywords: Inequality, Globalization, Co-integration, ARDL model, Iran

JEL Classification: D31, D63, F15.

\section{Introduction}

Globalization is defined as the free movements of goods, services and capital across borders. It is a contentious process by which the western market economies have effectively spread 
across the globe. Although it does not constitute a new phenomenon, it is viewed as an inexorable integration of markets, nations and technologies to a degree never witnessed before in a way that is enabling individuals, and corporations to reach around the world further, faster, deeper and more economically than ever before. By contrast, some groups of scholars and activists view globalization as an ideological project of economic liberalization that subjects states and individuals to more intense market forces.

Globalization is widely believed to have had a generally positive impact on global economic growth. But the effect of globalization on employment and the distribution of incomes have been intensely debated in recent years.

As Nielson, Alderson and Beckfield (2005) describe, a wide variety of economic and social trends have been associated with rising income inequality where it occurred:

- Changes Affecting Labor Supply e.g., immigration, trends in education, female labor market participation, rise of part-time labor, government transfers.

- Changes Affecting Labor Demand e.g. technological (skill-biased) change, increased international trade, outsourcing.

- Changes in Labor Market Institutions e.g., Changes in minimum wages and the degree of unionization, tax law changes, deregulation.

In particular, the effect of globalization on employment and the distribution of incomes have been much discussed in recent years. Political changes and trade liberalization have accelerated the international integration of product, labor, and capital markets. Rapid technological change has contributed to lowering costs of trade in goods and services adding momentum to the process of international integration.

A significant number of countries have experienced important increases in income inequality in recent years. The evolution of incomes at the top percentiles of the income distribution has received a lot of attention in the public debate and globalization has often been pinpointed as one of the possible causes of diverging revenues.

For lower-income, or developing countries, being allowed expanded opportunity to exploit their comparative advantage through the fragmentation of industry or through taking advantage of freer trading opportunities, often means being given the opportunity to develop labour-intensive industries, i.e., taking advantage of their relatively large endowments of low unit cost labour. The export of labour-intensive goods has been the basis for the fast economic growth rates experienced by most of the rapidly growing developing countries of the past 30 years. But freeing up the import of these goods into the high-income countries has been a source of increasing income inequality in these countries, with the inevitable resistance by those losing out.

As a developing country, the impact of globalization on inequality in Iran would be much more serious. Figure 1 \& 2 show the Gini coefficient and globalization trends in Iran over the period 1977-2007. 


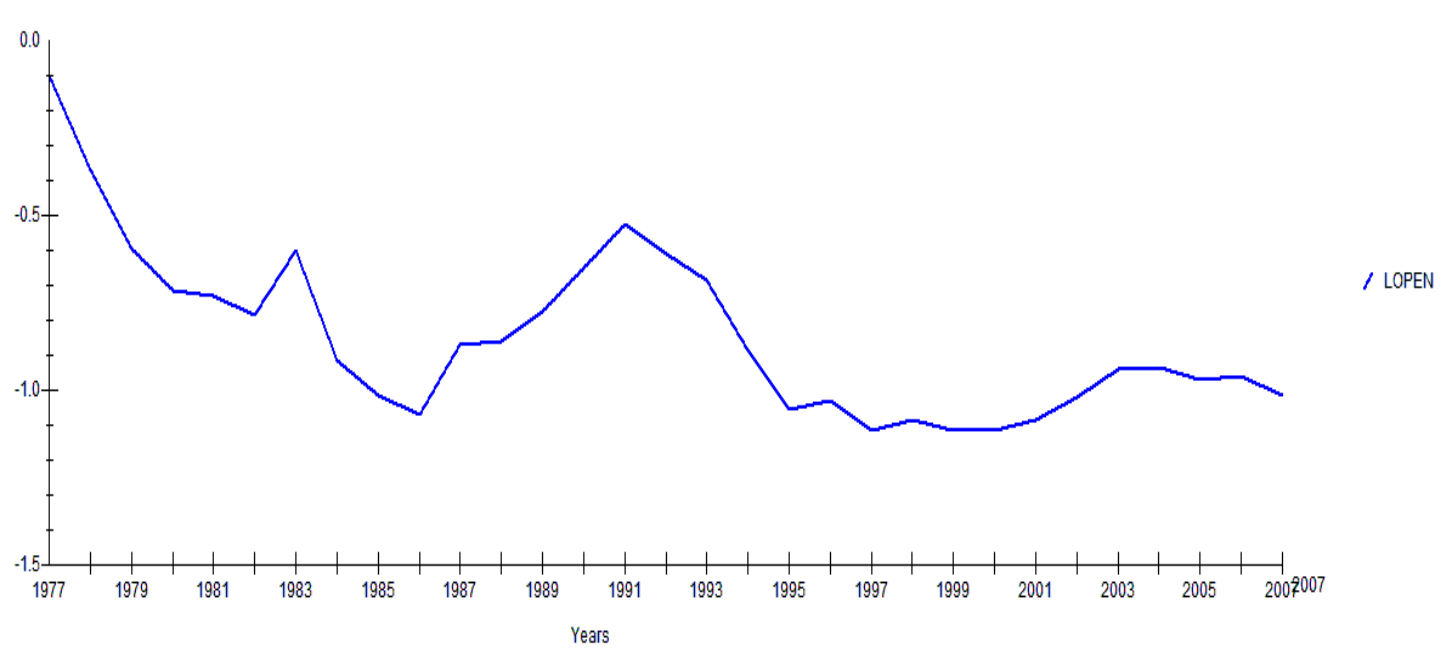

Figure 1. Time series plot of LOPEN

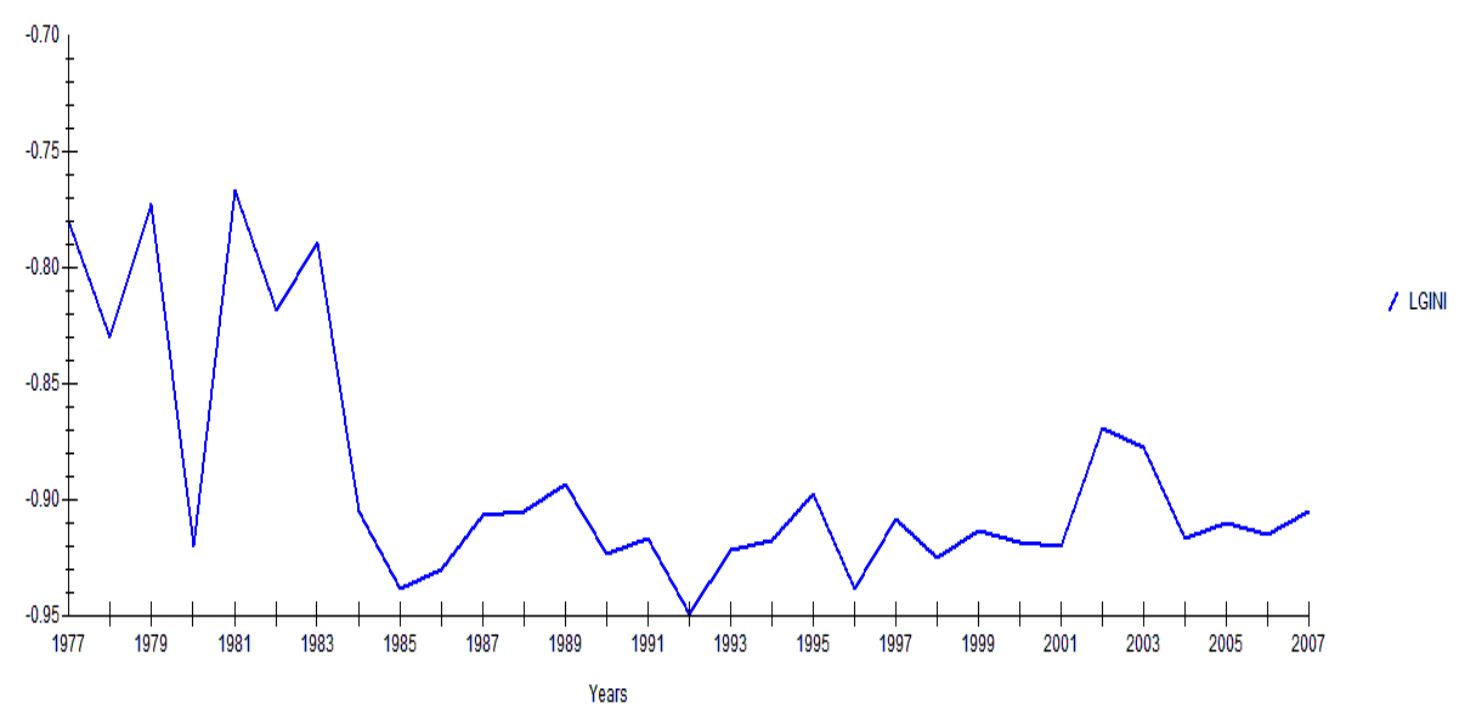

Figure 2. Time series plot of LGINI

The paper is organized as follows. The next section begins by reviewing some of the existing studies on globalization and inequality. Section 3 describes data and mathematical model employed to capture the influence of globalization on distribution of income. Section 4 presents empirical results of the estimation. Finally conclusions are presented in Section 5.

\section{Review of Literature}

Globalization and inequality is a highly debated topic in the literature. Various studies prove that globalization increases inequality, whereas numerous other studies claim that globalization reduces inequality. 
The neoliberal argument says that the distribution of income between all of world's people has become more equal over the past two decades and the number of people living in extreme poverty has fallen, for the first time in more than a century and a half. It says that these progressive trends are due in large part to the rising density of economic integration between countries, which has made for rising efficiency of resource use worldwide as countries and regions specialize in line with their comparative advantage (Hunter Wade,2004)

Barro (2002) for instance, attributed changes in the widened income inequalities to trade expansion. Mundell (1957) suggested that FDI flows contribute to a reduction of income inequalities in developing countries. Feenstra and Hanson (1997) argued that FDI flows into developing countries cause a higher wage for skilled workers than unskilled workers, resulting in widened income inequalities. Figini and Gorg (1999) argued that, initially, wage inequality increases with the FDI inflows, but, as blue-collar workers become skilled, that decreases in turn. Feenstra and Hanson's (1997) and Figini and Gorg's (1999) works were restricted to the Mexican and Irish cases, respectively and they did not compare the explanatory powers of the competing hypotheses.

Harrison and Hanson (1999) for Mexican economy and Barro (2002), for some of the nation showed that increased trade will worsen the income distribution . Findings of Mah (2003), contrary to the above investigations, revealed no relation between globalization and income distribution for Korean case. In general an explicit relation between trade liberalization and income distribution is not supported and it is highly dependent on the condition of the nations.

Levinsohn (2000) believes that globalization may benefit the poor in some countries and harm those in other countries. Also, even within a country, globalization is likely to help some of the poor and hurt others.

Neutel and Heshmati (2006) examined relationship between globalization, inequality and poverty. Their results from cross-national regression analysis show that there is a significant relationship between globalization and income inequality.

James (2002) analyzed the causes of globalization in terms of transaction costs and focuses on information and communication technologies and technical change and foreign investment deriving globalization and their application to developing problems in Africa.

Milanovic (2002), attempted to discern the effects of trade and foreign investment on relative income shares of low and high deciles using household budget surveys. The results showed that the effects of openness on income distribution depend on the country's initial income level. At the very low levels the rich benefit, but the situation changes as income levels rises.

Nissanke and Thorbecke (2010), Focus on different manifestations of globalization and channels through which globalization affects poverty and inequality, the case studies in the present volume cover the spectrum from broad macroeconomic regional and country analyses to more micro-oriented studies in different settings in Central and South America. The case studies illustrate that the impact of globalization poverty and inequality is extremely context specific. 
Wallace, Gauchat and Fullerton (2011), examined the impact of five measures of globalization (global capital, foreign direct investment, exports, foreign born non-citizens, and foreign born citizens) and six measures of labor market transformation (deindustrialization, corporate restructuring, bureaucratic burden, casualization, bad jobs, and multiple job holding) on metropolitan-level earnings inequality of full-time, full-year workers 16 years and older. Their study makes several major contributions to the literature. First, they updated and extended the long line of studies on metropolitan earnings inequality. Second, they showed that these various dimensions of globalization and labor market transformation exert independent and mainly polarizing effects on the earnings distributions of metropolitan areas, net of controls for labor market structure and socio demographic variables. Third, they demonstrated the benefits of looking at the causes of inequality in the upper and lower tails of the earnings distribution. Finally, they developed a procedure to estimate counterfactual values of earnings inequality for all major metropolitan areas in the US in 2000. In the process, they provided a comprehensive accounting of the impact of globalization and labor market transformation on metropolitan earnings inequality.

Basu (2006) studied the relation between globalization, inequality, and marginalization, within and across countries. He reviewed the existing evidence on globalization and global inequality and argues, using a simple theoretical model, that the two are inter-connected. It discusses alternative policies to counter extreme poverty and inequality.

Adams (2008) examined the impact of globalization on income inequality for a cross-section of 62 developing countries over a period of 17 years (1985-2001). The results of the study indicated that globalization explains only $15 \%$ of the variance in income inequality. More specifically, the results show that (1) strengthening intellectual property rights and openness are positively correlated with income inequality; (2) foreign direct investment is negative and significantly correlated with income inequality but this is not robust to different model specifications; (3) the institutional infrastructure is negatively correlated with income inequality.

Bergh and Nilsson (2010) examined if the KOF Index of Globalization and the Economic Freedom Index of the Fraser institute are related to within-country income inequality using panel data covering around 80 countries 1970-2005. The results showed that the freedom to trade internationally is robustly related to inequality, also when adding several control variables and controlling for potential endogeneity using GMM. Social globalization and deregulation is also linked to inequality. They found that reforms towards economic freedom seem to increase inequality mainly in rich countries, and social globalization is more important in less developed countries. Finally, they showed that monetary reforms, legal reforms and political globalization do not increase inequality.

Sato and Fukushige (2009) analyzed the determinants of the Gini coefficient for income and expenditure in South Korea between 1975 and 1995. In both cases, they did not find support for the Kuznets inverted-U hypothesis. From an economic globalization viewpoint, the opening of goods markets reduces income inequality in both short run and long run. On the other hand, the opening of capital markets increases income inequality in both periods. 
Lee (2006) examined the impact of globalization on the income inequality in Europe. The panel estimation results covering 14 European countries over the period 1951-1992, showed that foreign direct investment has raised income inequality and that the Kuznets hypothesis is valid. It offers a broad picture of growth, equity, and globalization in Europe.

Miller (2001) used a computable general equilibrium model to consider whether globalization can explain declining relative wages of unskilled workers in the U.S. since the late 1970s. Most of the increase in wage inequality results from changes in the structure of production, part of which could be explained by outsourcing, which involves unskilled-intensive parts of the production process moving to low-income countries.

Bigsten and Durevall (2006), analyzed the evolution of wage inequality in Kenya during 1964-2000. Their measure of wage inequality is the ratio of wages in manufacturing to wages in agriculture, which can be seen as an indicator of sectoral wage inequality or as a proxy for skilled to unskilled wages. They found that changes in relative wages have primarily been driven by the degree of openness, while other factors such as the capital-labor ratio, educational attainment, relative labor productivity, and the ratio between agricultural and manufacturing prices had no significant effect. They conclude that international market integration has reduced wage inequality in Kenya.

Acemoglu (2003) developed a model where labor market institutions creating wage compression also encourage more investments in capital-intensive technologies. These technologies increase the productivity of less-skilled workers and have prevented a fall in their relative wages. But Wan and Chen (2007) discussed China's globalization process and estimated an income generating function, incorporating trade and FDI variables. They found that globalization constitutes a positive and substantial share of regional inequality and the share rises over time. Also economic reform characterized by privatization exerts an increasingly significant impact on regional inequality, and finally the relative contributions of education, location, urbanization and dependency ratio to regional inequality have been declining.

Fischer (2001), showed that liberalization cause to increased income distribution in the case of nations with great supply of land while in the case of nations with high level of capital it cause to more equal income distribution. Bhasin and Annim (2005) also showed the importance of the policy combination.

Rasekhi and Ranjbar(2009) examined trade openness impact on the speed of convergence for D8 members by using powerful panel data technique during time 1975-2004. Their Results indicated that trade openness has significant and positive effect on speed of convergence among D8 members.

\section{Data and Econometric Methodology}

There are several approaches to co-integration: e.g., the residual based Engle-Granger (1987) test, maximum likelihood based Johansen (1991, 1992), and Johansen and Juselius (1990) test. These approaches require that all variable be integrated of the same order; otherwise create inefficiency which affects the predictive powers (Kim, Leybourne \& Newbold, 2004; 


\section{Al Macrothink}

Business and Economic Research

ISSN 2162-4860

2012, Vol. 2, No. 2

Perron, 1989, 1997). Pesaran, Shin and Smith (2001), developed the Autoregressive Distributive Lag Model or ARDL bounds testing approach to co-integration which is better suited to small samples (Haug, 2002).

We utilize the ARDL approach to establish the existence of long-run and short-run relationships. ARDL is extremely useful because it allows us to describe the existence of an relationship in terms of long-run and short-run dynamics without losing long-run information.

The objective of this paper is thus to evaluate the effect of globalization on income distribution using annual data over 1977-2007. An ARDL representation of above equation is as below:

$$
\begin{aligned}
& \text { LGINI }_{t}=\alpha_{0}+\sum_{i=1}^{p} \lambda_{1} \text { LGINI }_{t-i}+\sum_{i=0}^{q_{1}} \lambda_{2} \text { LOPEN }_{t-i}+\sum_{i=0}^{q_{2}} \lambda_{3} \text { LCGDP }_{t-i}+\sum_{i=0}^{q_{3}} \lambda_{4} \text { LCPI }_{t-i} \\
& +\sum_{i=0}^{q_{4}} \lambda_{5} \text { LUN }_{t-i}+\sum_{i=0}^{q_{5}} \lambda_{6} \text { LGR }_{t-i}+\sum_{i=0}^{q_{6}} \lambda_{7} \text { LSTAX }_{t-i}+\sum_{i=0}^{q_{7}} \lambda_{8} \text { LSFER }_{t-i}+\varepsilon_{t}
\end{aligned}
$$

Where:

GINI= Gini coefficient is used as measure of income inequality. It varies between 0 and 1 , the former indicates the completely equal and latter indicates the absolutely unequal. In other words, higher values of the coefficient show more inequality in society.

OPEN $=$ Trade intensity index which are defined as $[(\exp$ ort + import $) / G D P] \times 100$ is used as measure of globalization.

CGDP $=$ per capita real GDP

$\mathrm{UN}=$ unemployment rate

$\mathrm{CPI}=$ consumer price index

$\mathrm{GR}=$ ratio of government expenditure to GDP

STAX $=$ the total share of income and wealth tax on the total tax revenue

SFER= disturbance of exchange rate (the difference between the official exchange rate and unofficial exchange rate) and $\varepsilon_{t}$ is assumed to be a white noise error process. All variables are expressed in natural logarithms.

First of all data has been tested for unit root. One of the methods to test whether series is stationary or not is Dickey-Fuller (DF) (1981), DF test is very important in terms of measuring which degree stationary series have, but it does not consider an autocorrelation in disturbance term. If disturbance term contains autocorrelation, DF test is invalid. In this situation, by adding lagged terms of dependent variable to explanatory variable, Generalized Dickey Fuller (Augmented Dickey-Fuller) is used.

The ADF test states series are whether stationary or not, can be defined as follows: 


$$
\begin{array}{r}
\Delta Y_{t}=Y_{0}+\alpha t+\Phi Y_{t-1}+\sum \Phi_{i} Y_{t-i}+u_{t} \\
\Delta Y_{t}=Y_{t}-Y_{t-1}
\end{array}
$$

Where: Dependent variable $\left(Y_{t}\right)$; Constant term $\left(Y_{0}\right)$; Trend variable(t); and Stochastic disturbance term $\left(u_{t}\right)$.

There are hypothesis to test series

$$
\begin{aligned}
& H_{0}: \Phi=0 \quad\left(Y_{t} \text { is non-stationary }\right) \\
& H_{1}: \Phi \neq 0 \quad\left(Y_{t} \text { is not non-stationary }\right)
\end{aligned}
$$

$\mathrm{ADF}$ is a regress test using each series own lagged terms with big differences. Many econometric programs satisfy ADF test statistics. If calculated t-value of variable is greater than ADF critical t-value then $H_{0}$ is rejected and thus the data is stationary. In addition, computer programs give the McKinnon critical values simultaneously that helps us to understand whether series are stationary or not at a 1\%,5\%,10\% levels. It can be decided by comparing these values with ADF test statistics whether series are stationary or not. If ADF test statistic is greater than McKinnon critical values absolutely, the series are stationary at that level. For instance, if ADF test statistic were greater than McKinnon critical value for 5\% levels but less than McKinnon critical value for $1 \%$ level, then series is stationary at $5 \%$ levels but non-stationary at $1 \%$ level. In such a situation, it is necessary to take all results at 5\% levels (Brooks, 2002).

We start by conducting a bounds test for the null hypothesis of no co-integration. In the ARDL bounds testing approach, the calculated F-statistic is compared with the critical value tabulated by Pesaran (1997) and Pesaran, Shin and Smith (2001). If the test statistics exceeds the upper critical value, the null hypothesis of a no long-run relationship can be rejected regardless of whether the under lying order of integration of the variables is 0 or 1. Similarly, if the test statistic falls below a lower critical value, the null hypothesis is not rejected. However, if the test statistic falls between these two bounds, then decision about co-integration is inconclusive. The critical bounds are taken from Pesaran and Pesaran (1997). When the order of integration of the variables is known and all the variables are $\mathrm{I}(1)$, the decision is made based on the upper bound. Similarly, if all the variables are I(0), then the decision is made based on the lower bound. The null hypothesis of no co-integration is: $\lambda_{1}=\lambda_{2}=\lambda_{3}=\lambda_{4}=\lambda_{5}=\lambda_{6}=\lambda_{7}=\lambda_{8}=0$ and the alternative hypothesis of: $\lambda_{1} \neq \lambda_{2} \neq \lambda_{3} \neq \lambda_{4} \neq \lambda_{5} \neq \lambda_{6} \neq \lambda_{7} \neq \lambda_{8} \neq 0 \quad$ implies co-integration among the series.

The ARDL method estimates $(p+1)^{k}$ number of regressions in order to obtain the optimal 
lag length for each variable, where $\mathrm{p}$ is the maximum number of lags to be used and $\mathrm{k}$ is the number of variables in the equation. If there is evidence of a long-run relationship (co-integration) among the variables, the following long-run model is estimated. The next stage entails the estimation of the error correction equation using the differences of the variables and the lagged long-run solution, and determines the speed of adjustment of returns to equilibrium. A general error correction representation of equation is given below:

$$
\begin{aligned}
& \Delta \text { LGINI }_{t}=\mu+\sum_{i=1}^{p} \alpha_{i} \Delta \text { LGINI }_{t-i}+\sum_{j=1}^{q} \beta_{j} \Delta \operatorname{LOPEN}_{t-j}+\sum_{k=1}^{q} \gamma_{k} \Delta L C G D P_{t-k}+\sum_{l=1}^{q} \phi_{l} \Delta L C P I_{t-l} \\
& +\sum_{m=1}^{q} \varpi_{m} \Delta L U N_{t-m}+\sum_{p=1}^{q} \varphi_{p} \Delta L G R_{t-p}+\sum_{r=1}^{q} \delta_{r} \Delta L S T A X_{t-r}+\sum_{s=1}^{q} \eta_{s} \Delta L S F E R_{t-r}+\vartheta E C M_{t-1}+\varepsilon_{t}
\end{aligned}
$$

Here $\alpha, \beta, \gamma, \phi, \varpi, \varphi, \delta$ and $\eta$ are the short-run dynamic coefficients of the model's convergence to equilibrium and $\vartheta$ is the speed of adjustment.

\section{Empirical Results}

Table 1 reports the results of unit root test applied to determine the order of integration among time series data. ADF Test has been used at level and first difference under assumption of constant and trend.

Table 1. Results of the Dickey-Fuller unit root test in levels and first differences

\begin{tabular}{|c|c|c|c|c|}
\hline \multirow{2}{*}{ Variable } & \multicolumn{2}{|c|}{ Level } & \multicolumn{2}{c|}{ First differences } \\
\cline { 2 - 5 } & Intercept & Intercept and trend & Intercept & Intercept and trend \\
\hline LGINI & -2.8371 & -2.5230 & -10.6576 & -10.6212 \\
LOPEN & -3.6038 & -3.6350 & Static & Static \\
LCGDP & -1.6779 & -2.6416 & -3.0660 & -5.1557 \\
LUN & -3.7234 & -2.8391 & -5.0928 & -5.6211 \\
LCPI & -0.16309 & -2.4168 & -3.0939 & -3.6150 \\
LGR & -1.9711 & -1.6426 & -4.3777 & -4.6450 \\
LSTAX & -2.7395 & -2.6390 & -5.4711 & -5.5176 \\
LSFER & -1.6724 & -1.9565 & -4.5465 & -4.4784 \\
5\% Critic Value & -2.9627 & -3.5671 & -2.9665 & -3.5731 \\
\hline
\end{tabular}

Note: The number in parentheses indicates the appropriate order of lag lengths determined via SIC.

*denotes statistically significant at $5 \%$ level.

Results clearly indicate that the index series except for trade intensity index are not stationary at level but the first differences of the logarithmic transformations of the series are stationary. Therefore, it can be safely said that series are integrated of order one I(1).

The next step is where equation 1 is estimated to examine the long-run relationships among the variables. As suggested by Pesaran and Shin (1999) and Narayan (2004), since the observations are annual, we choose 2 as the maximum order of lags in the ARDL and estimate for the period of 1977-2007. In fact, we also used the Schwarz-Bayesian criteria (SBC) to determine the optimal number of lags to be included in the conditional ECM(error 
correction model), while ensuring there was no evidence of serial correlation, as emphasized by Pesaran, Shin and Smith (2001).

Table 2. ARDL(2,0,2,2,0,2,1,2) selected based on SBC

\begin{tabular}{|c|c|c|c|}
\hline Regressor & Coefficient & S. Error & T Ratio \\
\hline LGINI(-1) & -0.19691 & -0.077567 & $-2.5386(0.035)$ \\
LGINI(-2) & 0.28838 & 0.072314 & $3.9878(0.004)$ \\
LOPEN & 0.21132 & 0.024367 & $8.6724(0.000)$ \\
LCGDP & -0.23561 & 0.079520 & $-2.9630(0.018)$ \\
LCGDP(-1) & -0.32543 & 0.062797 & $-5.1822(0.001)$ \\
LCGDP(-2) & -0.079460 & 0.053466 & $-1.4862(0.176)$ \\
LCPI & 0.18510 & 0.046475 & $3.9828(0.004)$ \\
LCPI(-1) & -0.24950 & 0.065849 & $-3.7889(0.005)$ \\
LCPI(-2) & 0.10921 & 0.044125 & $2.4751(0.038)$ \\
LUN & 0.057637 & 0.033241 & $1.7339(0.107)$ \\
LGR & 0.13302 & 0.019892 & $6.6868(0.000)$ \\
LGR(-1) & 0.16402 & 0.024155 & $6.7901(0.000)$ \\
LGR(-2) & 0.060859 & 0.020478 & $2.9719(0.018)$ \\
LSTAX & -0.013637 & 0.014504 & $-0.94020(0.375)$ \\
LSTAX(-1) & -0.040868 & 0.018098 & $-2.2582(0.054)$ \\
LSFER & -0.0043955 & 0.0016285 & $-2.6992(0.027)$ \\
LSFER(-1) & 0.0049933 & 0.0019600 & $2.5476(0.034)$ \\
LSFER(-2) & 0.0083375 & 0.0016470 & $5.0623(0.001)$ \\
INPT & 2.3307 & 0.40945 & $5.6923(0.000)$ \\
\hline$R^{2}=0.99017$ & $\overline{R^{2}}=0.96806$ & D.W & \\
$X_{s c}^{2}(1)=3.43[0.06]$ & & $(1)=1.2988[.254]$ & \\
$X_{N}^{2}(2)=.34056[.560]$ & & $(1)=.34898[.840]$ & \\
\hline
\end{tabular}

Table 2 indicates that macroeconomic variables significantly explain the Gini coefficient. The value of R-Bar-Squared is 0.96 which indicates a high degree of correlation among variables.

The F-test is used for testing the existence of long-run relationship. The calculated F-statistic (5.6497) is higher than the upper bound critical value at 5 per cent level of significance (3.553), using restricted intercept and no trend. Furthermore, the calculated F-statistic is higher than the upper bound critical value at 5 per cent level of significance (3.883), using restricted intercept and trend. This implies that the null hypothesis of no co-integration cannot be accepted at 5 per cent level and therefore, there is a co-integration relationship among the variables.

After analyzing the bound test for co-integration, next step is to estimate the coefficient of the long-run relationships.

Table 3. Estimated Long Run Coefficients for selected ARDL Model

\begin{tabular}{|c|c|c|c|}
\hline Regressor & Coefficient & S. Error & T Ratio \\
\hline LOPEN & 0.23260 & 0.033803 & $6.8810(0.000)$ \\
\hline
\end{tabular}




\begin{tabular}{|c|c|c|c|}
\hline LCGDP & -0.70498 & 0.14531 & $-4.8516(0.001)$ \\
LCPI & 0.049328 & 0.011180 & $4.4120(0.002)$ \\
LUN & 0.063439 & 0.038606 & $1.6432(0.139)$ \\
LGR & 0.39392 & 0.048268 & $8.1612(0.000)$ \\
LSTAX & -0.059992 & 0.23543 & $-2.5482(0.034)$ \\
LSFER & 0.0098348 & 0.0023462 & $4.1917(0.003)$ \\
INPT & 2.5653 & 0.56537 & $4.5374(0.002)$ \\
\hline
\end{tabular}

Table 3 displays the results of long-run coefficients under ARDL approach. Results clearly indicate that the variables except for the unemployment rate have significant long-run effect on the Gini coefficient. Our findings suggest that increase in globalization, consumer price index, ratio of government expenditure to GDP and disturbance of exchange rate increase the income inequality and increase in per capita real GDP and LSTAX reduce the income inequality. The elasticity of the above-mentioned variables is $0.23,0.05,0.4,0.01,-0.70$ and -0.05 respectively.

Table 4. Error Correction Representation for the Selected ARDL Model

\begin{tabular}{|c|c|c|c|}
\hline Regressor & Coefficient & S. Error & T Ratio \\
\hline dLGINI1 & -0.28838 & 0.072314 & $-3.9878(0.002)$ \\
dLOPEN & 0.21132 & 0.024367 & $8.6724(0.000)$ \\
dLCGDP & -0.23561 & 0.079520 & $-2.9630(0.011)$ \\
dLCGDP1 & 0.079460 & 0.53466 & $1.4862(0.161)$ \\
dLCPI & 0.18510 & 0.046475 & $3.9828(0.002)$ \\
dLCPI1 & -0.10921 & 0.044125 & $-2.4751(0.028)$ \\
dLUN & 0.057637 & 0.033241 & $1.7339(0.107)$ \\
dLGR & 0.13302 & 0.019892 & $6.6868(0.000)$ \\
dLGR1 & -0.060859 & 0.020478 & $-2.9719(0.011)$ \\
dLSTAX & -0.013637 & 0.014504 & $-0.94020(0.364)$ \\
dLSFER & -0.0043955 & 0.0016285 & $-2.6992(0.018)$ \\
dLSFER1 & -0.0083375 & 0.0016470 & $-5.0623(0.000)$ \\
dC & 2.3307 & 0.40945 & $5.6923(0.000)$ \\
ECM(-1) & -0.90854 & 0.12818 & $-7.0879(0.000)$ \\
\hline \multicolumn{2}{|c|}{$\mathrm{F}=93.9951(0.000)$} & $\overline{\mathbb{R}^{2}}=0.97886$ & \\
& $\boldsymbol{R}^{2}=0.99350$ & & \\
\hline
\end{tabular}

The results of short-run coefficients indicate that the variables except for LSTAX have significant short-run effect on the Gini coefficient. According to results short-run, the relationship between globalization and income inequality is positive and significant. Thus, a $1 \%$ rise in the globalization increases income inequality by $0.21 \%$. Our findings suggest that a $1 \%$ increase in the consumer price index increases the income inequality by $0.18 \%$. As table 4 shows the relationship between per capita real GDP and the Gini coefficient is negative. This implies that a $1 \%$ increase in per capita real GDP reduces income distribution by $0.23 \%$. The estimates show a positive impact of unemployment rate on income inequality. A $1 \%$ rise in unemployment rate increases income inequality by $0.06 \%$. For Iran, a $1 \%$ increase in the 
ratio of government expenditure to GDP increases income inequality by $0.13 \%$. The increase in disturbance of exchange rate and LSTAX tends to decrease income inequality, but their affect is negligible.

The short-run adjustment process is examined from the ECM. If the coefficient of ECM lies between 0 and -1 , the correction to GINI in period $t$ is a fraction of the error in period $t-1$. In this case, the ECM causes the GINI to converge monotonically to its long-run equilibrium path in response to the changes in the exogenous variables. If the ECM is positive or less than -2 , this will cause the GINI to diverge. If the value is between -1 and -2 , the ECM will produce dampened oscillations in the GINI around its equilibrium path.

Following Kremers, Ericson and Dolado (1992) who argued that the significant lagged error-correction term is a more efficient way of establishing co-integration, we concluded the existence of a strong co-integration relationship among variables in the model. However the coefficient of $\operatorname{ECM}(-1)$ is -0.90854 , indicating that any deviation from the long-run equilibrium between variables is corrected about $90 \%$ for each period and suggests a high speed of convergence to equilibrium. Approximately $90 \%$ of disequilibrium from the previous year's shock converge back to the long-run equilibrium in the current year.

To complement this study it is important to investigate whether the above long run relationship we found are stable for the entire period of study. In other words, we have to test for parameter stability. The methodology used here is based on the cumulative sum (CUSUM) and the cumulative sum of squares (CUSUMSQ) tests proposed by Brown, Durbin and Evans (1975). Unlike the Chow test, that requires break point(s) to be specified, the CUSUM tests can be used even if we do not know the structural break point. The CUSUM test uses the cumulative sum of recursive residuals based on the first $n$ observations and is updated recursively and plotted against break point. The CUSUMSQ makes use of the squared recursive residuals and follows the same procedure. If the plot of the CUSUM and CUSUMSQ stays within the 5 percent critical bound the null hypothesis that all coefficients are stable cannot be rejected. If however, either of the parallel lines are crossed then the null hypothesis (of parameter stability) is rejected at the 5 percent significance level.

Figure $3 \& 4$ show that both CUSUM and CUSUMSQ are within the critical bounds of 5\% so it indicates that the model is structurally stable.

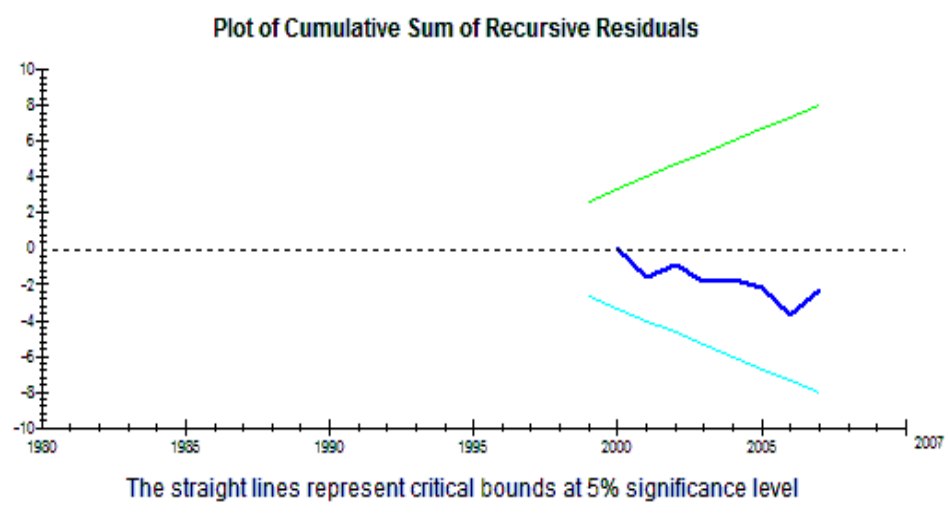

Figure 3. Cumulative Sum of Recurive Residuals 


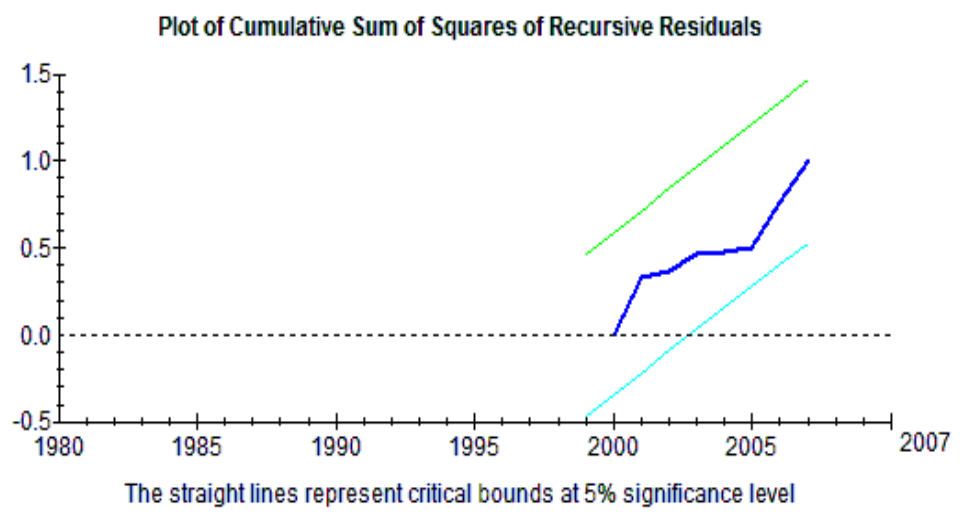

Figure 4. Cumulative Sum of Squares Recurive Residuals

\section{Conclusion}

The paper explores the existence of long run relationship between globalization and income inequality in Iran using the ARDL bounds testing approach to co-integration and the error correction model (ECM) for short run relationships.

ADF unit root test examines stationary of the series. The series are co-integrated. The results of short-run and long-run coefficients showed that the relationship between globalization and the Gini coefficient is positive. In other words, a $1 \%$ rise in the globalization increases income inequality.

Furthermore, consumer price index, ratio of government expenditure to GDP increase income inequality and per capita real GDP reduces income inequality.

From the short-run results we found a correctly signed and statistically significant coefficient of $\operatorname{ECM}(-1)$ which is a more efficient way of establishing co-integration. Additionally stability test also conducted. The results of CUSUM and CUSUMSQ tests indicated that all coefficients in the short and long-run models are stable.

\section{Acknowledgement}

We gratefully acknowledge the project reported here was supported by a grant-in-aid of research from Ferdowsi University of Mashhad (contract code: 2/16001) without which this research would not have been possible.

\section{References}

Acemoglu, D. (2003). Cross-country inequality trends. Economic Journal, 113, 121-149. http://dx.doi.org/10.1111/1468-0297.00100

Barro, R. J. (2002). Inequality and growth in a panel of countries, Jornal of Economic Growth, 5, 5-32. http://dx.doi.org/10.1023/A:1009850119329

Basu, K. (2006). Globalization, poverty, and inequality: What is the relationship? What can be done? World Development, 34(8), 1361-1373. http://dx.doi.org/10.1016/j.worlddev.2005.10.009 
Bergh, A., \& Nilsson, T. (2010). Do liberalization and globalization increase income inequality? European Journal of Political Economy, 26(4), 488-505. http://dx.doi.org/10.1016/j.ejpoleco.2010.03.002

Bhasin, V., \& Annim, S.K. (2005). Impact of elimination of trade taxes on poverty and income distribution in Ghana, Working Paper.

Bigsten, A., \& Durevall, D. (2006). Openness and wage inequality in Kenya, 1964-2000. World Development, 34(3), 465-480. http://dx.doi.org/10.1016/j.worlddev.2005.08.005

Brooks, C. (2002). Introductory Econometrics For Finance, Cambridge University Press.

Brown, R. L., Durbin, J., \& Evans, J.M. (1975). Techniques for Testing the Consistency of Regression Relations Over Time, Journal of the Royal Statistical Society, 37, 149-92.

Dickey, D. A., \& Fuller W. A., (1981), Likelihood ratio statistics for autoregressive time series with a Unit Root , Econometrica, 49(4), 1057-1072. http://dx.doi.org/10.2307/1912517

Engle, R. F., \& Granger, C. W. J. (1987). Co-integration and error correction representation: Estimation and testing. Econometrica, 55, 251-276. http://dx.doi.org/10.2307/1913236

Feenstra, R. C., \& G. Hanson, (1997). Foreign direct investment and alternative wages; evidence from mexico's maquiladoras, Journal of International Economics, 42(3/4), 371-393. http://dx.doi.org/10.1016/S0022-1996(96)01475-4

Figini, P., \& Gorg, H. (1999). Multinational companies and wage inequality in the host country: the case of Ireland. Weltwirtschaftliches Archive, 135, 594-612. http://dx.doi.org/10.1007/BF02707386

Fischer, R. D. (2001). The evolution of inequality after trade liberalization, Journal of Development Economics, 66, 555-579. http://dx.doi.org/10.1016/S0304-3878(01)00174-2

Harrison, A., \& Hanson, G. (1999). Who gains from trade reform? Some remaining puzzles, $\begin{array}{llll}\text { Journal of Development } & \text { Economics, } & 59, & 125-154 .\end{array}$ http://dx.doi.org/10.1016/S0304-3878(99)00008-5

Haug, A. (2002). Temporal aggregation and the power of co-integration Tests: A Monte Carlo Study. Oxford Bulletin of Economics and Statistics, 64, 399-412. http://dx.doi.org/10.1111/1468-0084.00025

Hunter Wade, R. (2004). Is globalization reducing poverty and inequality? World Development, 32(4), 567-589. http://dx.doi.org/10.1016/j.worlddev.2003.10.007

James, J. (2002). Technology, globalization and poverty. Edward Elgar, Cheltenham, UK.

Johansen, S., \& K. Juselius (1990). Maximum likelihood estimation and inference on co-integration with applications to the demand for money. Oxford Bulletin of Economics and Statistics, 52, 169-210. http://dx.doi.org/10.1111/j.1468-0084.1990.mp52002003.x

Johansen, S. (1991). Estimation and hypothesis testing of co-integrating vectors in Gaussian vector autoregressive models. Econometrica, 59, 1551-1580. 
http://dx.doi.org/10.2307/2938278

Johansen, S. (1992). Co-integration in partial systems and the efficiency of single equation $\begin{array}{lllll}\text { analysis. Journal of } & \text { Econometrics, } & 52, & 389-402 .\end{array}$ http://dx.doi.org/10.1016/0304-4076(92)90019-N

Kim, T-K., Leybourne, S., \& Newbold, P. (2004). Behaviour of Dickey-Fuller Unit-Root Tests Under Trend Misspecification. Journal of Time Series Analysis, 25, 755-764. http://dx.doi.org/10.1111/j.1467-9892.2004.02000.x

Kremers J. J., Ericson, N. R., \& Dolado J. J. (1992). The Power of co-integration tests, Oxford Bulletin of Economics and Statistics, 54, 325-347. http://dx.doi.org/10.1111/j.1468-0084.1992.tb00005.x

Lee, J. E. (2006). Inequality and globalization in Europe. Journal of Policy Modeling, 28(7), 791-796. http://dx.doi.org/10.1016/j.jpolmod.2006.04.013

Levinsohn, J. (2000). Globalization and poverty, national bureau of economic research, prepared for meeting of the G-24, Geneva, Switzerland.

Mah, J. S. (2003). A note on globalization and income distribution the case of Korea, 1975-1995. Journal of Asian Economics, 14(1), 157-164. http://dx.doi.org/10.1016/S1049-0078(02)00244-0

Milanovic B. (2002). Can we discern the effect of globalization on income distribution? Evidence from household budget surveys. World Bank Policy Research Paper, pp. 2876.

Miller, T. C. (2001). Impact of globalization on U.S. wage inequality: Implications for policy. The North American Journal of Economics and Finance, 12(3), 219-242. http://dx.doi.org/10.1016/S1062-9408(01)00053-5

Mundell, R. A. (1957). International trade and factor mobility. American Economic Review, 47(3), 321-335.

Narayan, P. K. (2004). Reformulating critical values for the bounds F-statistics approach to co-integration: An application to the tourism demand model for Fiji. Discussion Papers, Department of economics, Monash university, Australia.

Neutel, M., \& A. Heshmati (2006). Globalization, Inequality and Poverty Relationships:A Cross Country Evidence, IAZ Discussion Paper, No. 2223.

Nielson, F., Alderson, A., \& Beckfield, J. (2005). Exactly how has income inequality changed? Patterns of distributional change in core societies. Luxembourg Income Study Working Paper Series, No. 422.

Perron, P. (1989). The Great Crash, the Oil Price Shock, and the Unit Root Hypothesis. Econometrica, 57, 1361-1401. http://dx.doi.org/10.2307/1913712

Perron, P. (1997). Further Evidence on Breaking Trend Functions in Macroeconomic $\begin{array}{lllll}\text { Variables. } & \text { Journal } & \text { 355-385. }\end{array}$ 
http://dx.doi.org/10.1016/S0304-4076(97)00049-3

Pesaran, H. M., Shin, Y. \& Smith, R. J. (2001). Bounds testing approaches to the analysis of level relationships. Journal of Applied Econometrics, 16, 289-326. http://dx.doi.org/10.1002/jae.616

Pesaran, H. M., \& Shin, Y. (1995). Autoregressive Distributed Lag Modelling Approach to Co-integration Analysis. DAE Working Paper Series No. 9514, Department of Applied Economics, University of Cambridge.

Pesaran, H. M., \& Shin, Y. (1999). Autoregressive Distributed Lag Modelling Approach to Co-integration Analysis, Chapter 11, in Storm, S., (ed.), Econometrics and Economic Theory in the $20^{\text {th }}$ Century: The Ragnar Frisch Centennial Symposium. Cambridge University Press: Cambridge.

Pesaran, H. M., Shin, Y. \& Smith, R. (1996). Testing the Existence of a Long-Run Relationship. DAE Working Paper Series No. 9622, Department of Applied Economics, University of Cambridge.

Pesaran, H. M., \& Pesaran, B. (1997). Microfit 4.0: Interactive Econometric Analysis. Oxford University Press: England.

Rasekhi, S., \& Ranjbar, O. (2009). Impact of Trade Openness on Income Per Capita Convergence Speed: Evidence from D8 Group, Useful Letter, 72, 109-134.

Sato, S., \& Fukushige, M. (2009). Globalization and economic inequality in the short and long run: The case of South Korea 1975-1995. Journal of Asian Economics, 20(1), 62-68. http://dx.doi.org/10.1016/j.asieco.2008.07.002

Suleiman. (2005). The Impact of Investment and Financial Intermediation on Economic Growth: New Evidence from Jordan Abstract.

Wallace, M., Gauchat, G., \& Fullerton, A. S. (2011). Globalization, labor market transformation, and metropolitan earnings inequality. Social Science Research, 40(1), 15-36. http://dx.doi.org/10.1016/j.ssresearch.2010.07.001

Wan, G. L. M., \& Chen, Z. (2007). Globalization and Regional Income Inequality: Empirical Evidence from Within China. Review of Income and Health, Series 53, No. 1.

\section{Copyright Disclaimer}

Copyright reserved by the author(s).

This article is an open-access article distributed under the terms and conditions of the Creative Commons Attribution license (http://creativecommons.org/licenses/by/3.0/). 